\title{
Impact of Microfinance Intervention on Rural Poverty Alleviation in Nigeria: An Application of Difference in Differences Technique
}

\author{
Taofeek Aremu Kasali PhD \\ School of Business and Management Studies, Moshood Abiola Polytechnic, Abeokuta, Nigeria
}

\begin{abstract}
In this study, Difference-in-Differences methodology was used to assess the impact of microfinance loan on rural poor in Nigeria. The sample is classified into four groups: the microfinance loan beneficiaries (treatment group) before obtaining the loan and after the programme implementation. Likewise the non-beneficiaries (control group that were also qualified but could not get the loan) were considered before their application for the loan and after the programme was implemented. The result revealed that microfinance loan has favourable contributions to poverty alleviation in the study area. However, there is still need for government aid in order to make the poor people benefit more from the microfinance programme and enhance economic development. Government should support the MFIs with funds that would be disbursed at concessionary interest rates. In addition, provision of more physical, social and economic facilities would encourage the establishment of more MFIs in the rural areas.
\end{abstract}

Keywords: economic development, poverty, microfinance, difference in differences, Nigeria

DOI: $10.7176 / \mathrm{JESD} / 11-16-06$

Publication date:August $31^{\text {st }} 2020$

\section{Introduction}

No meaningful economic development can be achieved without adequate policies and programmes that will empower the poor to have their means of livelihood. This is in line with the assertion that there is no justification for any country to be regarded as progressing or advancing when majority of her citizens are languishing in poverty and hunger. Poverty and hunger mostly affect the rural households. It also prevents the rural community from investing in their own means of development. Poverty, as believed by some few elites is a necessary evil that can serve as a motivator to the poor. To this group of people, the poor are being motivated to work as a result of the deprivations and denial of customs and other social activities acceptable to the society. Poverty is a multi-faceted fabric which involves economic, social, cultural and psychological dimensions. The consequences of poverty are dehumanizing, devastating and traumatic. Realizing this phenomenon, development institutions like World Bank, United Nations (UN) and International Monetary Fund (IMF) instigated the development of various projects and programmes that would contribute to the improvement of the life of the poor, by ensuring health improvement and sustainable growth and development (Ssewamala,Sperber,Zimmerman \& Karimli, 2010).

Records have confirmed that about half of the world's population (about three billion people) lives on income of less than two dollars a day (Goel \& Rishi, 2012). It was also attested that one child out of five living in these poor communities die before the age of five. No wonder, in September 2000, the United Nations declared Millennium Development Goals (MDGs) to enhance adequate worldwide development. This program was mainly established to improve the wellbeing of the poor and those who are vulnerable to abject poverty. In essence, reduction of poverty and hunger is the major policy thrust of Millennium Development Goals (Kalirajan \& Singh, 2009)

It has been observed that poverty restricts the school age children from attending schools due to lack of fund. This had led to higher adolescent birth rates among girls in particular. As a result, the already economically overstressed poor communities are more devastated. Consequently, the Millennium Development Goal number one is to half poverty and hunger worldwide by 2015 . This has made poverty eradication to be more political, ethical, social and economic imperative of mankind. Therefore multidimensional measures in all human endeavours should be used to reduce poverty like policy measures that will cut across the sectors like education and well remunerated labour option (Smith, 2010). Provision of basic commodities and services is another measure that can alleviate poverty. This can be used in particular to ensure social equity (Abdel-Baki, 2012).

Hunger that connotes the inability to obtain minimum calories and protein food in a country is one of the important dimensions of poverty. According to 2013 World Hunger and Poverty Facts and Statistics, almost one in eight people in the world were affected by malnutrition from 2010-2012. The report further ascertained that "almost all the hungry people, 852 million, live in developing countries, representing 15 percent of the population of developing countries". In Sub-Saharan Africa, hunger rises 2 percent annually since 2007. It has been affirmed through statistics that from Year 2010 to 2012, the population of people affected by hunger increased from 175 million to 239 million. Consequently, nearly one in four Africans are hungry. The number of hungry people also rise from 13 million in 2004 - 2006 to 16 million in 2012 in the Developed regions (FAO, 2012) cited in 2013 World Hunger and Poverty Facts and Statistics. Malnutrition, which is one of the indicators of poverty, has more damages particularly in children. For example, malnourished pregnant women give birth to children with low birth 
weight, high child mortality rate, learning disabilities, mental retardation, blindness and poor health.

Several studies have been carried out on the effect of Government policies on poverty alleviation. But due to the problem of paucity of accurate and quality data and the problem of methodology, most of the researchers concentrate on the macro and urban effects. This further widens the gap between the urban and rural inequality which is at the detriment of the rural communities.

Despite the importance and increasing activities of MFIs in poverty alleviation in Nigeria, little efforts have been advanced to study the effect of microfinance programmes on the rural poor particularly in the study area of this project. This study has as its main aim to provide empirical evidence on the impact of microfinance loan in reducing poverty on the rural poor in Nigeria; using data collected through field survey by the author.

This exercise will be the foremost study in this geographical area when an independent research will be conducted to study the impact of microfinance on the rural poor. The study is expected to spur the government policy directed to empower the poor with adequate credit facilities and necessary infrastructure for economic development.

The study is presented in five sections. Following the introduction is the empirical studies which reviewed the relevant studies of the subject matter. This is followed by the methodology of this study. Then the analysis and discussion are used to present the outcome of the study before the paper is concluded with the summary and policy implications.

\section{Empirical Studies}

The Capability Approach Theory has been extensively used in the empirical studies. For instance, since 1990 the Capability Approach (CA) model has been exposed to tremendous empirical works that are too numerous to mention. The theory has been found to possess the ability of directing the attention of the public towards the neglected dimensions of human well-being by comparing the merits and demerits of intervention programmes. It also gives the opportunity of using much more data of "functionings" and "capabilities" for more critical evaluations rather than economic indicators like Gross Domestic Product Per Capita and Growth rate (Wells, 2013). In the past two decades, CA has been in the fore front as a leading alternative when it comes to choosing the standard economic framework for analyzing poverty, inequality and human development, social justice, living standards and rights and duties (Clark, 2005). Sen's Capability Approach has also been commended for expanding the frontier of knowledge in the evaluation of qualities of life, targeting people as end in themselves rather than means to economic procedures, confirming the heterogeneity inherent in humans as individuals, groups, cultures, norms and values. In addition, the theory has proved its practical application as the base of scientific research for human needs, poverty, wellbeing, gender disability, inequality, human security and human rights. It has also served as the main source of discussion in several books and conferences (Clark, 2005). Apart from being an appropriate framework designed to measure the individual's wellbeing and social arrangements, CA is also used to assess the social cost-benefit analysis and evaluate the impact of policies on the peoples capabilities (Robeyns, 2005).

The Capability Approach Theory has been extensively used by the international organisations. For instance, since 1990, the United Nations Human Development Programme (UNDP) issued its Annual reports based on Human Development Index (HDI) developed through CA to compete with the popular Gross Domestic Product per capita figures. Furthermore, in recent times the Multidimensional Poverty Index (MPI) was developed by researchers at the Oxford Poverty and Human Development Initiative (OPHI) through the theory and is included in the UNDP's Human Development Reports from 2010 onwards. From these measures, it has been revealed that the MPI has demonstrated the quality of the theory by providing different pictures of international and regional poverty than Income poverty. The MPI has further depicted the differences in the magnitude and depth of poverty level from country to country and has finally assisted the policy makers to enact the policies that will eradicate the specific country's poverty problem. In fact, Sen's work has been adapted in various researches and studies across different disciplines; and development practitioners have used it for diverse missions. Prominent among them are the assessment of quality of life, well-being and human development by Robeyns (2005) and Alkire (2005); Anderson (1999), Alexander (2008) and Nussbaum (2000) used CA to develop a capability based 'Theory of Justice'. In essence, CA is a development construct that has really assisted to portray the human development approach in form of a development paradigm that explains different types of policy choice like poverty (FukudaParr, 2003).

In view of the above enumerated benefits and practical applications that this study is based on, the underpinning theory for this research work is Capability Approach Theory while the Household Economic Portfolio Model (HEPM) is used for the empirical work. The question to pose here is how does Capability Approach Theory measure the impact of microfinance? Going by the capability approach, financial exclusion means the poor are being denied access to credit because of the financial risks and high cost of administration, any measure that assists them to surmount this problem then enhance their capabilities. Therefore the theory can be a valuable framework to assess the effectiveness of microfinance. Furthermore, the capability perspective advocates that actual development must involve the overall welfare of the individual. This means that microfinance should 
not only improve the access to formal credit by the poor to establish a new business or expand an existing one, but it should also contribute to improvement on other dimensions of poverty like health, education, standard of living, expenditure (consumption) and income of the beneficiaries. This study therefore employs multidimensional conceptual framework to examine these variables in the Nigeria context. In addition, the current study assesses the extent by which microfinance has improved the multidimensional poverty indicators (both economic and noneconomic measures) of the beneficiaries. This agrees with Hulme (2000) which opines that impact studies should apply pluralistic approaches and should not be restricted to single method whose weaknesses may be difficult for the researcher to eliminate.

In his research on microfinance and poverty Khandker, (2005) used Panel Data from Bangladesh to measure the effect of microfinance on poverty reduction. The results of the study show that having the opportunity to use micro-credit leads to reduction in poverty, particularly for female participants and also contribute to poverty reduction in the entire study area. He therefore concludes that microfinance assists not only the poor participants but also contributes to the development of local economy.

Assessment of microfinance impact on income has revealed mixed results. While some studies affirm positive impact of microfinance on income, it is less significant in others. As a development on the assessment methodology of microfinance impact of Gaiha and Thapa (2006), Gaiha and Nandhi (2007) conducted an empirical study to assess the impact of microfinance through self-help group and the role of microfinance in rural development and poverty alleviation in Maharashtra, Pune District of India. Data were collected in six villages consisting respondents who belong to treatment and control groups. The independent variables identified include age, education, wealth, occupation, caste, income, savings, dependence on informal loan and women autonomy. The findings of the study revealed that the effect of microfinance is unsatisfactory on income but there is improvement on caste, landlessness, illiteracy and savings. Loans were used mainly for health and children education, and production related expenses. Women empowerment was confirmed but with longer working hours. There was also reduction in violence.

Pati and Lyngdoh (2010) assessed the socio-economic impact of microfinance on individual family in Meghalaya, Northeast India. The study used PSM and Difference-in-Differences (DID) method to analyse data collected from 150 clients and 75 non-clients (all women) of microfinance banks. The results revealed that microfinance loan makes significant increase in income, expenditure, savings, wellbeing, education, health, capacity building and access to social amenities for the clients than non-clients. In a similar study, Jamal (2008) evaluated the socio-economic impact of microfinance in Pakistan. DID method was used to analyse data that consist of 3,400 borrowers and non-borrowers from six large microfinance institutions in Pakistan. The identified explanatory variables include expenditure, child education, women empowerment, assets, health status, household size, dependency ratio; and household head characteristics like age, education and wealth. The outcomes of the analysis confirm that microfinance generates income and smooth consumption. There is also increase in school children enrollment but reduction in women empowerment.

Expenditure per head in the household or per capita expenditure is another dimension for the measurement of impact of microfinance on poverty. Ifelunini and Wosowei (2012) examine the role of microfinance on poverty reduction among women entrepreneurs in South-South Nigeria. Data were collected from 400 respondents, comprising 200 beneficiaries and 200 non beneficiaries in eight local governments of the zone. Logit model, Propensity Score Matching and Instrumental variable methods were used to analyse the data. Explanatory variables for the study include age, household size, education, marital status, business time and location of residence. The outcome of the study revealed that access to microfinance has positive impact on per capital expenditure of women entrepreneur; while places of residence and household size have negative impact on per capita expenditure; education has positive effect on the latter.

Health is another poverty dimension that can be used to assess the impact of microfinance loan. Mohindra and Haddad (2005) used conceptual framework backed with Sen's capability approach to assess the impact of participating in microfinance programme on the health status, particularly the women's welfare. It was hypothesized that increase in income as a result of microfinance loan participation can help to reduce the health hazards for women; as people in poverty are usually vulnerable to poor health. The study identified variables like access to safe drinking water, good sanitation, adequate housing, access to economic resources and access to public goods and services as some of the determinants of low health hazards. The study concludes that microfinance is a promise intervention programme to improve women capability in health. The more a woman participates in the programme, the greater is the propensity to achieve good health.

Afrane (2002) also evaluated the impact of microfinance programme interventions on the beneficiaries in Ghana and South Africa. Variables like sales, assets, income, expenditure, water, toilet health, number of rooms occupied, housing; food/nutrition and education were used to measure the welfare impact of the loan beneficiaries sampled in Ghana and South Africa. Although the study considered the before and after the event, it failed to include the control group (non-beneficiaries). This serves as constraint in comparing the counterfactual situation with the factual conditions of the target group. The study also gives less attention to family and religious matter. 
All this are considered in the present study which create another opportunity to fill the identified gap and make literature contribution in Sub Saharan Africa. Afrane (2002) concludes that microfinance programmes have succeeded in the improvement of the beneficiaries' welfare as small loans increased income within a short period of 8-12 months and the performance of women outweighs their male counterparts. This corroborates the findings of Pitt and Khandker (1996) which evaluates the impact of Grameen Bank and similar targeted credit programmes in Bangladesh. In this study, multipurpose quasi experimental household survey was conducted in 87 villages in rural Bangladesh. The findings revealed that as a result of participating in microfinance programme, there was improvement in income, welfare and assets position, consumption, children school enrolment; and women participants yield more impact on poor households than men.

Measuring the outreach and sustainability of microfinance loan has been considered as part of the evaluation of the efficiency impact of the loan (Morduch, 2000). Coleman (2006) carried out an empirical study on the outreach and impact of microfinance loan on the poor in Northeast Thailand. The study seeks to know who benefits from microfinance patronage and how much was the benefit. Variables like assets, credit-saving worthiness, wealth, savings, income, health and education status, household size, age, business assets and assets less debt were identified for the impact measurement. The study used survey method for borrowers and non-borrowers with Logit and Tobit regression analyses. The outcome of the study revealed that banks don't patronize the rural poor because of high risks and costs of small loans; also, the microfinance programmes do not reach the poor who are supposed to be their primary target but instead, the rich and influential committee members benefit from the services of the banks.

Diagne and Zeller (2001) conducted an empirical research to determine factors responsible for the accessibility to formal and informal credit in rural Malawi and its impact on food security and income of participants. Data were collected from 404 households in 45 villages of five districts where four MFIs were operating. Variables identified for outcome illustration include assets, age, education and household size. The findings show that participants in microcredit end up in low income when compared with non-participants. There was no significant impact of the loan on crop income, per capital income, food security and nutritional status of the participants. The study concludes that access to microcredit alone cannot serve as a "panacea" to poverty reduction but should be accomplished with social and economic infrastructural facilities that would provide good roads, health and education for human capital development.

As a response to Coleman (2006) and other researchers with similar assertions, Khandker and Samad (2013) conducted a study to verify whether the microcredit participants in Bangladesh are trapped in poverty and debt as earlier claimed by critics. A long panel data for 20 years (1990/91-2010/11) was analysed. The results revealed that microcredit participants were not trapped in debt or poverty. Instead, it was discovered that microcredit participants gained tremendously, more than non-participants, with increase in income; improvement in consumption, assets ownership and children schooling. In addition, the microcredit participants have higher household net worth and reduction in poverty and debt asset ratio. These views were further supported by similar study carried out by Khandker and Samad (2014) which investigates the dynamic effect of microcredit in Bangladesh. Sharing similar views, (Imai, Gaiha, Thapa, \& Annim, 2012) investigated the impact of microfinance at Macro level. The study utilized cross-sectional data covering 48 countries in developing regions and 2003/2007 panel data covering 61 countries; extracted from Microfinance Information Exchange (2010) and World Bank (2011), to consider the Gross Domestic Product (GDP) per capita and share of credit in GDP. It was discovered that countries with high microfinance portfolio tend to have lower levels of poverty incidence. Also, the study confirms that microfinance significantly reduces poverty at macro level; therefore, there is need to reinforce more funds from government and development finance institutions to MFIs. In general, the paper concludes that it is a mistake to assume that microfinance lacks the "magic" to conquer poverty, neither is it an overestimation that microfinance serves as a panacea for poverty reduction.

\section{Difference -in- Differences (DID) Approach}

In recent times, the Difference -in- Differences (DID) approach has become a popular method for estimating the impact of intervention programmes for non-purely experimental data (Athey \& Imbens, 2006). In view of the fact that it takes some time for the impact of a programme to be manifested on the participants, the observed outcomes may not only reflect only the effect treatment but influenced by other observed and unobserved factors like individual capability and effect of other government policies. It is therefore expedient to remove such influence in order to estimate the real impact of the programme event. The DID method is designed to resolve such problems by comparing the individuals who did not undergo the same treatment but have the same attributes with the treated group and then deduct the difference in the outcome variables of control individuals over time from the difference of the treated individuals in order to estimate the impact.

Some recent studies on the impact of microcredit programmes based on DID approach have used Panel data. For instance, Khandker (2005) used panel data to assess the impact of microcredit programme in Bangladesh. The findings revealed that microcredit significantly reduce poverty among the poor participants within the rural 
economy in Bangladesh. Although panel data has its peculiar problems in estimation, it offers some remarkable advantages over cross-sectional data in evaluating the impacts of microfinance. For instance, it helps to analyse the dynamics of the effects of microfinance loan over time (Khandker \& Samad, 2014). It is expected that panel data models are reliable in the estimation of impact of programme by 'differencing out the effect of unobserved factors' (Li, 2010). In as much as it is good to control for unobserved effects by differencing the panel data in two separate years; collecting such panel data is a difficult task because of the time constraints and costs involved. In the first place, it is easier to collect a single cross section, particularly for individuals, than to collect set of panel data. Consequently, the latter involves the collection of data through a survey and keeping track of the individual in order to carry out the second survey as a follow-up. Locating people for the follow-up survey is usually tedious and difficult. Even for units such as firms, it may be impossible to relocate some firms because some might have merged with other companies or wound up their businesses. To solve this problem, there would be need to use large cross section data (Wooldridge, 2009 :459)

\section{Difference in Differences Estimation Method}

Difference-in-differences methodology can be used to measure the impact (effect) of a programme on population samples. To know the actual difference, two groups (control and treatment) are usually involved at different periods (before and after the programme implementation). Hence in this study, the sample is classified into four groups: the microfinance loan beneficiaries (treatment group) before obtaining the loan and after the programme implementation; likewise, the non-beneficiaries (control group that were also qualified but could not obtain the loan) were considered before their application for the loan and after the programme was implemented. The study adopts "before and after" approach for both the treatment and control groups in order to solve the problem of counterfactual situation of the loan beneficiaries and non-beneficiaries as explained by Heckman, Ichimura, \& Todd, (1998). This approach is necessary since there was no baseline data for the study to know the situation of the respondents before the loan period. This situation therefore makes recall memory technique the suitable option with the assumption that the respondents would be able to recall their situation fairly well before the microfinance loan application.

Following Wooldridge (2009:453-454) and Green (2012:156-157), the treatment group can be named T and $\mathrm{C}$ for the control group. Let $\mathrm{dT}$ equal one for the treatment group $\mathrm{T}$ and zero otherwise. Then let $\mathrm{d} 2$ connote a dummy variable for the after programme implementation time period, the equation of interest can be stated as:

$$
\mathrm{y}=\beta_{0}+\chi_{0} d 2+\beta_{1} d T+\lambda_{1} d 2 . d T \text { +other variables, }
$$

where $y$ is the outcome variable of interest (poverty alleviation in this study). $\lambda_{1}$ measures the effect of the programme. Excluding other factors in the regression, $\lambda_{1}$ will be the difference-in-differences estimator:

$$
\lambda_{1=}\left(\bar{y}_{2 T}-\bar{y}_{2 C}\right)-\left(\bar{y}_{1 T}-\bar{y}_{1 C}\right)
$$

where the bar connotes average, the first subscript connotes the period (time) and the second subscript connotes the group. Other variables are defined in the models.

Table 1 depicts the overall set up of difference-in-differences. In the table, the parameter $\lambda_{1}$, usually named the average treatment effect (measures the effect of microfinance programme on the average outcome of y), can be estimated in two ways viz:

(A) Compute the differences in averages between the treatment (beneficiary) and control (non-beneficiary) groups in each time period, and then difference the results overtime like what is shown in equation ii.

(B) Do the computation to get the change in averages over time for each of the treatment (beneficiary) and control (non-beneficiary) groups, and then find the difference of these changes. That is, simply write $\lambda_{1=}\left(\overline{\mathrm{y}}_{2 T}-\overline{\mathrm{y}}_{1 T}\right)-\left(\overline{\mathrm{y}}_{2 C}-\overline{\mathrm{y}}_{1 C}\right)$. Fundamentally, the estimate $\lambda_{1}$ does not depend on how the difference is done but can be shown by simple rearrangement.

\section{Table 1}

Description of the Difference-in-Differences Estimator

$\begin{array}{lclc} & \text { Before } & \text { After } & \text { After - Before } \\ \text { Control } & \beta_{0} & \beta_{0}+\lambda_{0} & \lambda_{0} \\ \text { Treatment } & \beta_{0}+\beta_{1} & \beta_{0}+\lambda_{0}+\beta_{1}+\lambda_{1} & \lambda_{0}+\lambda_{1} \\ \text { Treatment - Control } & \beta_{1} & \beta_{1}+\lambda_{1} & \lambda_{1}\end{array}$

Source: Adapted from Wooldridge (2009:454)

The difference-in-differences method has been described as one of the essential tools used for applied research in economics to measure the impacts of public interventions and other related treatments of interest on some important outcome variables (Abadie, 2005). It is based on the idea of using natural experiment to assess treatment effect where the use of truly experimental data is not feasible. The estimator works on the fact that in a situation where a part of the population is exposed to a treatment, a control group can be used to measure the temporal difference in the outcome that is not based on the effect of the treatment. 


\section{Methodology}

For the purpose of this study, a two-stage combined sampling technique is adopted. The first stage involves stratified random sampling. The second stage consists of purposive sampling (for non-beneficiary of microfinance) and simple random sampling (for beneficiary of microfinance).

Nigeria is grouped into six Geo-political zones. According to 2006 National Population Census, South West Geo-political zone has a population of 27,722,432 people out of the Nation's total population of 140,431,790. The people in the study area are mainly engaged in microenterprises, farming, light cottage industry, livestock business, motorcycle transport business, retailing, motor and motorcycle repairs, furniture works, tailoring, and other artisan works. Each zone contains states that mostly share some common values in terms of language, culture and other traditions with each other. Majority of the data collected is from Ogun state which is a replica of other states in the zone. Based on this justification, in the first stage Ogun State is classified based on three senatorial districts. Each district was also grouped for political and administrative convenience like the zones at the Federal level. From each Senatorial district, stratified samples were employed where three strata are formed based on the Senatorial districts. Two local government areas were selected randomly from each of the three strata. A total of six local government areas were selected randomly from 20 local government areas in Ogun state. In order to enhance the representation of sample, three local government areas were chosen from Osun and Oyo states based on the criteria of similarity in the historical antecedents, socio-cultural uniqueness, population size, occupation, language and proximity to the sampled local government areas in Ogun state. The total sample size of the study therefore comes from three out of the six states in the South-West geo-political zone of Nigeria.

In the second stage, simple random sampling was used to select 65 microfinance loan beneficiaries from each of the selected local government areas, and purposive sampling to select 65 non-beneficiaries (those who are eligible to take the loan and also into similar business with beneficiaries) from the same local government area In terms of targeted sample size, 1,170 respondents were contacted with the questionnaires.

\section{Model Specifications for Impact Estimation}

To achieve the objectives of this study, the difference-in-differences method is used to determine the impact of microfinance loan on poverty alleviation in the study area. This study evaluates the impact of Microfinance loan on rural poverty reduction.

Model: The Impact of Microfinance loan on Poverty Alleviation

The concept of poverty reduction has attracted the attention of some scholars. Empirical studies have identified some variables like inflation, age, household size, health problem, lack of savings and inadequate assets as the major causes of poverty (Chaudhry,2009; Roslan and Abd Karim,2009; Taylor and Xiaoyun, 2012; Yusuf, Shirazi, \& MatGhani, 2013).

In order to evaluate the variables that determine Poverty alleviation together with microfinance loan in the study area, the Binary logistic regression model was explored with DID approach.

Model for this study can be specified as follows:

$$
\begin{aligned}
& L_{i}=\ln \left(\frac{P_{i}}{1-P_{i}}\right)=\beta_{o}+\beta_{1} M_{F S}+\beta_{1 i} H E S T_{2 i}+\beta_{3} S L_{3 i}+\beta_{4} E P H_{4 i}+\beta_{5} T i S_{5 i}+\beta_{6} A G_{6 i}+\beta_{7} H H S_{7 i}+ \\
& \beta_{8} T_{8 i}+\beta_{9} \operatorname{DPry}_{9 i}+\beta_{10} \text { DHiSc }_{10 i}+\beta_{11} D N D_{11 i}+\beta_{12} D H D U n i_{12 i}+\beta_{13} \text { Dmarr }_{13 i}+\beta_{14} D D W i d_{14 i}+\varepsilon_{i}
\end{aligned}
$$

$\mathrm{P}_{\mathrm{i}}$ is a binary Dependent variable. $\mathrm{P}_{\mathrm{i}}=1$; if the person is not poor and $\mathrm{P}_{\mathrm{i}}=0$; if the person is poor.

The World Bank's Poverty line Index set at $\$ 1.25$ per day is used as a benchmark to measure the level of poverty (Chen \& Ravallion, 2008). That is, those whose income per day is below the Index were regarded as poor and those people that earn $\$ 1.25$ and above per day were categorized as non-poor.

Independent variables consist of:

MFS = Microfinance loan Status: 1 for Beneficiary and 0 for Non-Beneficiary;

HEST $=$ Health Status;

$\mathrm{SL}=$ Standard of Living;

$\mathrm{EPH}=$ Expenditure per Head;

TiS $=$ DID estimator of the effectiveness of microfinance loan

$\mathrm{AG}=$ Age of the Household head;

HHS = Household size;

$\mathrm{Ti}=$ Dummy variable for the period: 1 for After and 0 for Before;

DPry = Education dummy for primary education;

DHiSc $=$ Education dummy for High school;

DND = Education dummy for National Diploma;

DHDUni = Education dummy for Higher Diploma/University degree;

DMarr = Marital Status dummy for married parent household;

DDWWid = Marital Status dummy for single parent household 
It is hypothesized that microfinance loan increases the poverty alleviation (Khandker, 2005; Okpara, 2010). It is expected that the higher the educational attainment of the household head, the lower the poverty level in the household (NBS, 2007); while increase in age can make the household head to be poor particularly at their terminal working age (NBS, 2007). Poverty incidence also used to increase with the increase in household size as this is always calculated on per capita expenditure (NBS, 2007). The health status, standard of living and Expenditure per head are expected to reduce the poverty status or increase poverty alleviation; other things remain constant.

\section{Analysis and Discussion}

The estimated results indicate that the coefficient of Tistatus (DID estimator to explain the impact of microfinance loan before and after the treatment) has positive sign with poverty alleviation and is significant at 1 percent level. The effect shows that the beneficiary of microfinance loan would have higher probability of reduction in poverty status by almost 12 percent than the non-beneficiary from the loan, other variables remain constant. This implies that microfinance loan is effective in reducing poverty. This result is consistent with various studies (for example, see Asghar, 2012; Green et al., 2006). It is important to note that the variables of time and microfinance status are the instruments of TiS and are mainly to serve as control for the effect of before and after, and treatment and control, respectively. Thus, no specific interpretation will be performed on these two variables.

The health standard variable is significant at 1 percent level with negative sign. The marginal effect reveals that the overall health of the respondents has reduced the probability of getting higher poverty alleviation by 9 percent. This can be explained by the fact that the stress and challenges of the well to do entrepreneurs always have negative impact on their health standard as little or no time would be left for leisure and sports. The coefficient of Standard of Living is positive and significant at 1 percent level. This result shows that a proportionate increase in Standard of living would contribute to higher probability of the poverty alleviation by 11 percent. This result is consistence with the findings of Khandker (2005) and Okpara (2010) to mention just two.

Likewise, the Expenditure Per Head is significant at 1 percent level with positive sign. The effect of this result is that an increase in Expenditure per Head would induce higher probability of poverty alleviation by 33 percent. Also the household size variable is positive and significant at 1 percent level. This indicates that with one additional member of household there is probability of increase in the poverty alleviation of such household by 49 percent, other conditions remain same. This result shows that the larger the household size, the less the poverty status provided that such additional household member is in a working class and contributing positively to the household income.

The Dummy variables on Education show negative signs at different levels of significance. In general, this implies that compared to those without formal education, those with formal education (from primary school to higher education) have lower probability of poverty alleviation. For instance the Primary Education Dummy (DPry) result is significant at 1 percent level and shows that respondents with primary education would have lower probability of poverty alleviation by 13.2 percent than those with no formal education. All this imply that attainment of higher education by Microfinance beneficiary tends to involve more resources and time and may affect the household's welfare adversely in the short run, as education attainment is not a guarantee to reduction in poverty.

Marital status dummies have positive signs and are significant at 10 percent. The dummy for married parent household (Dmarried) shows that changing the marital status from single to married among the respondents would increase the probability of poverty alleviation by 8 percent.

The result also shows that marital status of single parent household (DDWid) would result in probability of 9 percent higher in poverty alleviation than that of unmarried household. This indicates that those married households and single parent households usually have large size members of household which may increase the household's wealth if the additional members are contributing positively to the overall income.

\section{Conclusion}

Conclusively, the analysis revealed that there is positive contribution of microfinance institutions towards the increase in the welfare of the households in the study area as a result of benefiting from microfinance programmes; but there is still need for improvement. This corroborates the findings of Morduch (1998). However, in order to make Microfinance Institutions (MFIs) more effective in the rural poverty reduction and to reach the target poor in the rural areas, the Government should create more enabling environment by improving on the rural physical infrastructural facilities. Also, constant development of health and education facilities is required. All this would reduce the operational costs of MFIs and make their services in the rural areas more attractive and effective.

It is also important that MFIs should always adjust their loan terms and conditions to reflect the condition of their potential rural clients. For example, repayment of short term loan on weekly basis may not be conducive for a rural peasant farmer whose harvesting period is seasonal with longer crop gestation period. However, MFIs should make client specific repayment schedules less stringent. Furthermore, cost reduction strategy can be embarked upon by MFIs which will enhance Corporate Governance by concentrating on the recruitment of the 
local educated people and engage less of their counterparts in urban centers. It is expected that loan marketers from local areas are more likely to be accustomed to rural poverty and be able to advocate for the patronage of microfinance programmes that will better the lot of the beneficiaries.

\section{REFERENCES}

Abadie, A. (2005). Semiparametric Difference- in-Difference Estimators. Review of Economic Studies Limited 72 , $1-19$.

Abdel-Baki, M. (2012). A community-based framework for poverty alleviation: the case of post-revolution Egypt. International Journal of Social Economics, 39(1/2), 81-96. doi:10.1108/03068291211188884

Afrane, S. (2002). Microfinance Interventions in Ghana and South Africa A Synthesis of Major Impacts and Lessons. Journal of Microfinance, 4(1), 37-58.

Alkire, S. (2005). The Capability Approach and Human Development.OPHI Working Paper.

Alexander, J. M. (2008). Capabilities and Social Justice The Political Philosophy of Amartya Sen and Martha Nussbaum. England: Ashgate Publishing Limited.

Alkire, S., \& Santos, M. E. (2013). Measuring Acute Poverty in the Developing World: Robustness and Scope of the Multidimensional Poverty Index. OPHI Working paper No . 59.

Anderson, E. S. (1999). What Is the Point of Equality?*. Ethics, 109(2), 287-337. Retrieved from http://www.jstor.org/stable/10.1086/233897

Asghar, N. (2012). Microfinancing for Poverty Reduction: An Emperical Study of Rural Areas of Tehsil GujratPakistan. International Journal of Advances in Management and Economics, 2.1, 34-40.

Athey, S., \& Imbens, G. (2006). Identification and inference in nonlinear difference-in-differences models. Econometrica, 74(2), 431-497. Retrieved from http://www.nber.org/papers/t0280

Chaudhry, I. S. (2009). Poverty Alleviation in Southern Punjab ( Pakistan ): An Empirical Evidence from the Project Area of Asian Development Bank. International Research Journal of Finance and Economics, 23(23), 23-32.

Chen, S. \& Ravallion, M. (2008). The Developing World Is Poorer Than We Thought, But No Less Successful in the Fight against Poverty.Policy Working Paper 4703, World Bank

Clark, D. A. (2005). The Capability Approach : Its Development, Critiques and Recent Advances.GPRG-WPS032 .

Coleman, B. E. (2006). Microfinance in Northeast Thailand: Who benefits and how much? World Development, 34(9), 1612-1638. doi:10.1016/j.worlddev.2006.01.006

Diagne, A. \& Zeller, M. (2001). Access to credit and its impact on welfare in Malawi (p. 169). Washington, D.C. Retrieved $\mathrm{http} / /$ books.google.com/books?hl=en\&lr=\&id=C9mEk3RregkC\&oi=fnd\&pg=PR4\&dq=Access + to + Credit + and+Its+Impact + on+Welfare+in+Malawi\&ots=6fAUnLGSCS\&sig=bofyn1Ikf8Dk-uT5FPX4eH9Cc_s

Fukuda-Parr, S. (2003). The Human Development Paradigm: Operationalizing Sen'S Ideas on Capabilities. Feminist Economics, 9(2-3), 301-317. doi:10.1080/1354570022000077980

Gaiha, R., \& Thapa, G. (2006). A methodology for assessment of the impact of microfinance on empowerment and vulnerability. Occasional Paper. Rome: International Fund for Agricultural Development Retrieved from http://citeseerx.ist.psu.edu/viewdoc/download?doi=10.1.1.116.4140\&rep=rep1\&type=pdf

Gaiha, R. \& Nandhi, M. . (2007). Microfinance, self-help groups and empowerment in Maharashtra. The Indian economy sixty. Retrieved

from https://socialpolicy.crawford.anu.edu.au/acde/asarc/pdf/papers/2007/WP2007_15.pd

Goel, G., \& Rishi, M. (2012). Promoting Entrepreneurship to Alleviate Poverty in India: An Overview of Government Schemes, Private-Sector Programs, and Initiatives in the Citizens 'Sector. Thunderbird International Business Review, 54(1), 45-57. doi:10.1002/tie

Green, W. H. (2012). Econometric Analysis (7th ed.). Upper Saddle River, N.J: Prentice Hall.

Green, C. J., Kirkpatrick, C. H., \& Murinde, V. (2006). Policy arena finance for small enterprise growth and poverty reduction in developing countries y. Journal of International Development, 18, 1017-1030. doi:10.1002/jid.1334.

Hulme, D. (2000). Impact Assessment Methodologies for Microfinance: Theory, Experience and Better Practice. World Development, 28(1), 79-98.

Ifelunini, I.A. \& Wosowei, E. C. (2012). Does Micro Finance Reduce Poverty among Women Entrepreneurs in South-South Nigeria ? Evidence from Propensity Score Matching Technique. European Journal of Business and Management, 4(21), 76-88.

Imai, K. S., Gaiha, R., Thapa, G. \& Annim, S. K. (2012). Microfinance and Poverty-A Macro Perspective. World Development, 40(8), 1675-1689. doi:10.1016/j.worlddev.2012.04.013

Jamal, H. (2008). Exploring the impact of microfinance in Pakistan (pp. 1-21). Retrieved from http://scholar.google.com/scholar?hl=en\&btnG=Search\&q=intitle:EXPLORING+THE+IMPACT+OF+MI 


\section{CROFINANCE+IN+PAKISTAN\#0}

Khandker, S. R. (2005). Microfinance and Poverty: Evidence Using Panel Data from Bangladesh. The World Bank Economic Review, 19(2), 263-286. doi:10.1093/wber/lhi008

Khandker S.R. \& Samad, H. A. (2013). Are Microcredit Participants in Bangladesh Trapped in Poverty and Debt? Poilicy Research Working Paper 6404; World Bank, (April).

Khandker S.R. \& Samad, H. A. (2014). Dynamic Effects of Microcredit in Bangladesh. Policy Research Working Paper 6821; World Bank, (March).

Li, X. (2010). An empirical analysis of microcredit on China rural household (Doctoral dissertation). Available from Lincoln University Digital Thesis.

Long, J. S. (1997). Regression Models for Categorical and Limited Dependent Variables. London: SAGE Publications.

Meyer, B. D., \& Sullivan, J. X. (2013). Consumption and Income Inequality in the U.S Since the 1960s.Technical report, Mimeo, University of Notre Dame, University of Chicago.

Mohindra, K. S., \& Haddad, S. (2005). Women's Interlaced Freedoms: A Framework Linking Microcredit Participation and Health*. Journal of Human Development, 6(3), 353-374. doi:10.1080/14649880500287662

Morduch, J. (1998). Does microfinance really help the poor? New evidence from Flagship programs in Bangladesh. New York University.

Morduch, J. (2000). The Microfnance Schism. World Development, 28(4), 617-629.

Nussbaum, M. (2000). Women's Capabilities and Social Justice . Journal of Human Development, 1(2), $29-54$. doi:10.1080/1464988002000874

National Bureau of Statistics. (2007). Nigeria poverty assessment 2007. Federal Republic of Nigeria: National Bureau of Statistics.

Okpara, G. C. (2010). Microfinance Banks And Poverty Alleviation in Nigeria. Journal of Sustainable Development in Africa, 12(6).

Pati, A.P. \& Lyngdoh, B. F. (2010). Microfinance Intervention and Socio-Economic Transformation: An Application of Propensity Score Matching and Difference-in-Difference Technique. Available at SSRN 1630268, 1-16. Retrieved from http://papers.ssrn.com/sol3/papers.cfm?abstract id=1630268

Pitt, M. M., \& Khandker, S. R. (1996). Household and Intrahousehold Impact of the Grameen Bank and Similar Targeted Credit Programs in Bangladesh Targeted Credit Programs in Bangladesh. World Bank discussion paper; 320 .

Robeyns, I. (2005). The Capability Approach: a theoretical survey. Journal of Human Development, 6(1), 93-117. doi:10.1080/146498805200034266

Roslan, A., \& Abd Karim, M. Z. (2009). Determinants of Microcredit Repayment in Malaysia: The Case of Agrobank. Humanity \& Social Sciences Journal 4(1).

Ssewamala, F. M., Sperber, E., Zimmerman, J. M., \& Karimli, L. (2010). The potential of asset-based development strategies for poverty alleviation in Sub-Saharan Africa. International Journal of Social Welfare, 19(4), 433443. doi:10.1111/j.1468-2397.2010.00738.x

Tang, S. (2002). Determinants of Repayment in Microcredit: Evidence from Programs in the United States *, 26(June), 360-376.

Taylor, J. G., Xiaoyun, L. I., \& South, L. (2012). China's changing poverty : a middle income country case study. Journal of International Development 24, 696-713. doi:10.1002/jid.

Wells, T. R. (2013). Essays on Amartya Sen's Capability Approach (Doctoral dissertation). Available from ErasmusUniversity Rotterdam Thesis.

Wooldridge, J. M. (2009). Introductory econometrics (4th ed.). Mason, OH 45040: South-Western Centage Learning.

World Hunger Education Service (WHES) (2013). World Hunger and Poverty Facts and Statistics. Available [on line] at: $<$ http://www.globalissues.org/article/26/poverty-facts-and-stats $>$.

Yusuf, M.B.O., Shirazi, N.S., \& MatGhani, G. (2013). The impact of Pakistan Poverty Alleviation Fund on Poverty in Pakistan: An emperical analysis.Middle-East Journal of Scientific Research,13(10), 1335-1344. 